\title{
DISKURS MATERINSTVA NA RASKRŠĆIMA IDEOLOGIJA U SLOVENAČKOJ (FEMINISTIČKOJ) ŠTAMPI
}

U tekstu se predstavlja slovenačka feministička štampa, čiji počeci datiraju u poslednjim godinama 19. veka. Pošto u jednom radu nije moguće dati panoramski pregled koji bi pokazao sve specifičnosti slovenačkog publicističkog diskursa koji se bavi feminističkim temama, fokus ovog teksta je na diskursu materinstva, u različitim istorijskim periodima. Pored toga, materinski mit je intenzivno prisutan u oralnoj slovenačkoj kulturi. Zbog delovanja katoličke crkve i nacionalizma, materinstvo spada u jednu od najjačih ideologija koje utiču na život žena i celokupnog društva pa je zbog toga često tematizovano u štampi sve do danas.

Ključne reči: materinstvo, slovenačka feministička štampa, časopisi Slovenka, Naša žena, Delta 
Materinstvo se obično vezuje za pravo na raspolaganje sopstvenim telom i, dalje, za problem abortusa. Prisutna je i tema viktimizacije majke, one koja mora detetu/društvu/naciji biti na raspolaganju svim svojim bićem, pa nema pravo na sopstvene želje. A ako ih ima, onda su te želje prvo porodični, a potom i društveni problem, koji uvek rezonira i u publicističkom diskursu. Različiti stavovi koji se formiraju u diskusijama o materinstvu, i koji će biti predstavljeni u nastavku ovog teksta, svoj izvor imaju u dve reprezentacije materinstva koje nalazimo u slovenačkom kulturnom sećanju. Prva reprezentacija odnosi se na tzv. mit o lepoj Vidi, koji se prvo pojavljuje u narodnoj baladi "Lepa Vida", u kojoj mlada žena ostavlja bolesno dete i muža. Različite su varijante tog mita u narodnom predanju: ženi su dosadili stari muž i bolesno dete; crnac je odveze u Španiju gde ce dojiti tuđe dete u zamenu za udoban život; sa crncem ode na barku, jer joj je on obećao lek za bolesno dete, a on je onda na prevaru odvede u Španiju. ${ }^{1}$ Ovde je reč o reprezentaciji slabe majke, koja svoje želje i čežnju ne može da usaglasi sa detetovim dobrom. ${ }^{2}$ Nasuprot tome, druga reprezentacija jeste tzv. cankarevska majka. Tu sliku formira Ivan Cankar u autobiografskim tekstovima u kojima tematizuje svoju grižu savesti u trenucima kad je povredio majku koja bi za njega sve uradila. Na primer, u tekstu "Greh" (1903) Cankar piše da je majka posetila njegovog brata Jožu kao đaka u Ljubljani, peške je krenula na dvadeset kilometara dug put, čekala ga je pred školom, ali se on pravio da je ne poznaje, jer se stideo nje. Kada ga je prijatelj pitao da li je to njegova majka, on je porekao. Kasnije mu je bilo žao i posramio se zbog svog postupka. U priči "Skodelica kave" (1910), pisac piše kod kuće pa poželi šoljicu kafe, koju nije lako pronaći jer je skupa. Kada mu majka, uloživši trud, donese nakon nekog vremena kafu, on je više ne želi i time povredi majku. U simbolističkom romanu $\mathrm{Na}$ klancu (1902) Cankar opet piše o svojoj majci. Francka je na početku romana

1 Jože Pogačnik, Slovenska Lepa Vida ali hoja za rožo čudotvorno. Motiv lepe Vide $v$ slovenski književnosti (Ljubljana: Cankarjeva založba, 1988).

2 U slovenačkoj katoličkoj štampi lik Lepe Vide povezuje se sa tzv. aleksandrinkama. To su bile žene, uglavnom iz severne Primorske, koje su krajem 19. veka otišle u Egipt i tamo radile kao sluškinje i dojilje. Iako su otišle jer je porodica zavisila od njihove zarade, katolička štampa, kao i društvo u načelu, stigmatizirali su ih zbog toga kao loše majke. Jernej Mlekuž, "The newspaper images of aleksandrinke and the national imagination", u: Mirjam Milharčič Hladnik, ur., From Slovenia to Egypt: Aleksandrinke's trans-Mediterranean domestic workers' migration and national imagination (Transkulturelle Perspektiven, Bd. 13), Göttingen: V\&R Unipress, 2015, str. 173-192. 
mlada žena koja sanja o boljem životu. Prva (nesretna) ljubav vodi je u težak brak, muž je ostavi samu sa troje dece, njen život je patnja i egzistencijalna borba. Najbliži joj je sin Lojze, kog su poslali na školovanje u Ljubljanu s obećanjem da će ga finansirati, ali na kraju majka mora da moli za novac jer svi na njega zaborave. Kad majka ostari, svi zaborave na nju. Kad majka umire, Lojze se vraća i razmišlja o smislu takvog života. Književna istorija je ove tekstove dobro ocenila - više puta je napisano da je Cankar svojim delima svojoj majci podigao najlepši spomenik, a slovenački filozof Slavoj Žižek je u vezi sa tim tekstovima rekao: majka slovenačke nacionalne fantazije je mučna figura, koja svoj muški naraštaj opterećuje grižom savesti. ${ }^{3}$ Uprkos ovom lucidnom uvidu, u kulturnom sećanju lik Cankarove majke još uvek simboliše žrtvu koju majka mora prineti za dete.

Još jedan razlog za dobru recepciju Cankareve slike majke verovatno ima veze sa činjenicom da se u katoličkim zemljama u 19. veku proširio Marijanski kult, ${ }^{4}$ koji je i na slovenačkom prostoru bio veoma dobro prihvaćen, posebno kada je kombinovan s nacionalizmom tog doba. ${ }^{5}$ Slovenački etnički prostor bio je tada deo Habzburške monarhije, u kojoj elita nakon 1848. godine, a uz pomoću katoličke crkve, opet uvodi slavljenje Marije. Ali, kasnije se pokazalo da ni molbe Bogorodici neće biti u stanju da ujedine etnički raznoliko stanovništvo kao što je to bilo moguce u prošlosti. U to doba praktikuju se različite varijante slavljenja Marije, takozvane Marijanske pesme, u kojima se naglašava da će Marija za svoje patnje biti nagrađena posle smrti u raju. ${ }^{6}$ Te pesme poručuju majkama da su patnje u njihovom svakodnevnom životu normalna pojava, te da bi trebalo da se u svojim mukama ugledaju na majku božju. Na taj način se u slovenačkom nacionalnom sećanju još

3 Slavoj Žižek, Jezik, ideologïja, Slovenci (Ljubljana: Delavska enotnost, 1987). Sociološkinja Ksenija Vidmar Horvat smatra da slovenački sin podleže želji svoje majke, odnosno ne napušta dom, dok sinovi srpske majke to čine, jer žele da se afirmišu u sferi javnosti, a možda i zbog mitologije u kojoj je arhetip muškosti srpski ratnik. Ksenija H. Vidmar, Zamišljena mati: nacionalizem in spol $v$ kulturi 2O. stoletja (Ljubljana: Znanstvena založba Filozofske fakultete, 2012), 31.

4 Prim. Luisa Accati, Il mostro e la bella. Padre e madre nell'educazione cattolica dei sentimenti (Milano, Raffaello Cortina Editore, 1998); Marina Warner, Alone of All Her Sex: The Myth and the Cult of the Virgin Mary (London: Picador, 1990).

5 To dokazuje i slika Maksima Gasparija "Bogorodica sa Isusom” u slovenačkoj narodnoj nošnji https://www.google.si/search?q=maksim+gaspari+devica + marija\&client $=$ safari\&channel $=$ mac_bm\&dcr $=0 \&$ source $=\operatorname{lnms} \&$ tb $\mathrm{m}=\mathrm{isch} \& \mathrm{sa}=\mathrm{X} \& \mathrm{ved}=$ oahUKEwi5ztGOqYTYAhUGxxQKHST3Au8Q_AUICigB\&biw=8oo\&bih=208\#imgrc=Oe1eEXi-A_4dvM.

6 Prim. Zmaga Kumer, Marija $v$ Svetem pismu in slovenskih ljudskih pesmih (Ljubljana: Družina, 2004). 
snažnije formirala slika o majci koja mora da se žrtvuje. Rasprave o materinstvu su se pojavljivale uglavnom u katoličkoj štampi u 19. veku. Tu je majka (obično iz seljačke porodice) važna kao oslonac mužu i u vaspitavanju dece. Majka personifikuje dom, zajednicu. Njen zadatak jeste da dete veže za sebe i za kuću, dok se svaki detetov pokušaj da se od nje udalji kažnjava njegovom grižom savesti. Da bi detetu dokazala svoju dominaciju, majka može da se prema njemu ophodi bez milosti. Kod Antona Martina Slomška (180o-1862), slovenačkog biskupa, pisca, pesnika i prvog slovenačkog blaženika u knjižici Drobtinice (1846) pronalazimo priču "Slaba mati, hudoben $\operatorname{sin"~}(1848)^{8}$ o zločincu koji je takav postao zbog majčinog popuštanja. Majka nije dozvoljavala ocu da kažnjava sina kad je bio nevaljao. Sinovljevi zločini išli su tako daleko da je na kraju kažnjen vešanjem. Ali, pre tog čina, zamolio je da još jedanput vidi svoju majku. Kad je došla da ga vidi, sin joj je naslonio glavu na grudi, zubima uhvatio njezinu dojku i ugrizao je, optužujući je da je ona, koja ga je dojila, kriva što on mora da umre jer ga nije vaspitala tako da se plaši loših postupaka i zločina. Pozitivan antipod toj priči u Drobtinicama jeste slika dobre majke koja svake subote uveče ispituje decu o svim gresima koje su učinili prošlog dana kako bi se pokajali u zajedničkoj molitvi. Otuđenje od majke ujedno je i otuđenje od crkve, jer je majka čuvarka sinovljevog pozitivnog odnosa prema religiji. ${ }^{9}$ U knjizi Štefana Kočevarja Slovenska mati (1882) majci se pripisuje zadatak da u deci probudi patriotska osećanja da bi oni bili verni svojoj otadžbini. Katolički diskurs tesno povezuje sliku majke, podvrgnute mukama, s realizacijom hrišćanske majke božje. Sudbina svake majke je patnja, a ta patnja je sasvim legitimna. Ženu koja ne želi da pati treba osuditi, to jest, u njoj je potrebno probuditi grižu savesti kako bi se ipak predala ženskoj sudbini. Ako do toga ne dođe, pišu katolički pisci, žena postaje histerična, njena deca su bolesna, slabog uma, puna srdžbe, tužna, plašljiva. To ne predstavlja nesreću samo za porodicu, nego za čitav narod. Teolozi poručuju ženama da je neprirodno ako ne žele da imaju decu, jer je najveća istina ta da svaka žena želi da postane majka. Jednako je, po njima, neprirodno “žensko pitanje”. Treba se sasvim podrediti materinstvu ili, kako piše teolog i biskup Mahnič, "[v]aspitanje zahteva svu njenu mudrost, sve njene brige, sve

7 To je bila knjižica sa pobožnim, biografskim, beletrističkim i muzičkim sadržajem, namenjena mladima kao vaspitno-pobožna literatura.

8 P.E.Z., "Slaba mati, hudoben sin”, u: Drobtince, ur. A. M. Slomšek (Graz: Lajkam, 1848), 184

9 A.M.Slomšek, "Skerbna mati v soboto zvečer”, u: Drobtince, ur. A. M. Slomšek (Graz: Lajkam, 1848), 209-212. 
njeno vreme". ${ }^{10}$ Ovde se majka vidi isključivo kao odgajateljica sinova, dok se podizanje ćerki ne razmatra. Ako se vaspitanje devojaka uopšte uzima u obzir, na njih se gleda isključivo kao na buduće majke, pa ih je potrebno za to pripremiti.

\section{II}

Krajem 80-ih godina 19. veka u časopisu Edinost o materinstvu se piše na nešto drugačiji način. Glavna akterka u toj debati bila je mlada učiteljica i feministkinja Marica Nadlišek (1867-1940), koja je već od 1888. pisala da je zadatak žena, u nacionalnom smislu, vaspitanje dece na patriotskoj osnovi. Zato nikoga nije iznenadilo kad su je pozvali da uređuje novi časopis Slovenka. ${ }^{11}$ Puna nade, htela je da u tom listu stvori prostor za objavljivanje što više autorki, ali je ujedno bila svesna da njih gotovo nema. Zbog toga je više puta morala da objavi tekstove početnica ili, pak, one tekstove koji nisu bili prihvatljivi za Ljubljanski Zvon i Dom i svet. Dok su ti časopisi bili ideološki jasno profilirani (liberali - klerikali), Slovenka je nastojala da ugodi kako politički raznolikim čitaocima, tako i manje obrazovanima, koji nisu imali preteranih umetničkih zahteva, to jest, široj publici u načelu. Slovenka je htela da bude napredna, ali nije želela da vređa katoličke krugove. Kako su njene čitateljke bile uglavnom žene, Marica Nadlišek je kao urednica morala čitati i pisma uvređenih učiteljica koje nisu više htele da se pretplaćuju na štampu u kojoj su izlazili tekstovi koji su ih ismevali. Isto tako, ugledne građanke su bile zabrinute za moralni ugled svog sloja. Hrabroj urednici tako nije preostalo ništa drugo nego da neguje literarni podmladak, te je Slovenka postala, kako je Marja Borštnik već primetila, vežbalište za nove književnice. Slovenka je okupila brojne i različite čitateljke; u ovom časopisu su "vežbale" značajne slovenačke predratne književnice (ne sme se zanemariti važna uloga Slovenke kada je reč o najvećoj slovenačkoj književnici Zofki Kvedrovoj, koja je u njoj objavila znatan broj svojih dela). Međutim, najveći doprinos časopisa ogledao se u brojnim teorijskim člancima i književnim prikazima, jer su tako autorke dobijale povratne informacije o svom radu. Slovenka je u 6 godišta objavila 355 priloga, kako pesama tako i proze svih žanrova. Ta činjenica dobija na važnosti ako uzmemo u obzir koliko su priloga autorke objavile

10Anton Mahnič, "Žensko poglavje. Naravni poklic ženske: bodi mati pa vzgajaj deco!”, Rimski katolik 16 (1894): 359-360.

11 Marta Verginella, ur., Slovenka: prvi ženski časopis (1897-1902) (Ljubljana: Znanstvena založba Filozofske fakultete, 2017). 
u štampi osrednjeg kvaliteta: u Domu i svetu 53 rada, u Ljubljanskom Zvonu tek 27. U oba časopisa broj radova tih autorki se povećava kada urednicu Maricu Nadlišek zameni Ivanka Anžič (1876-1960), koja se odlučuje za drugačiju uredničku politiku i daje manje prostora beletristici. Ona više pažnje posvećuje člancima o ženskom pokretu. Istovremeno, na raspolaganju joj stoji profilisana generacija spisateljica koje više ne pišu početničku poeziju i prozu, pa je tako Anžič bila u prilici da štampa samo najbolje tekstove, a same autorke su mogle zbog kvaliteta svojih radova da objavljuju i na drugim mestima. S vremenom, u časopisu Slovenka počinju da izlaze i tekstovi koje pišu muškarci.

Tekstove o materinstvu Slovenka je objavljivala od samog početka. Prva slovenačka feministkinja Elvira Dolinar (1870-1961), pod pseudonimom Danica, savetovala je čitateljke kako da odgajaju decu i naglašavala da majka na taj način odgaja i samu sebe, što joj omogućava unutrašnji razvoj. Važno je da majka bude uzor svojoj deci. ${ }^{12}$ U višim školama za devojke trebalo je učiti kako se neguju i odgajaju deca, a predavanja bi obuhvatala i anatomiju ženskog tela i higijenu. ${ }^{13}$ Odgovorno materinstvo može se postići samo dobrim i ispravnim odgojem devojaka, pisala je Zofka Kveder, ali je pritom kritički naglasila da se ipak više pažnje posvećuje tome kako naći muža. Konsekvence takvog odnosa prema devojkama su sudbonosne: pošto devojka ne zna dovoljno o životu i vaspitanju dece, ona je nedorasla problemima i zadacima sa kojima se u životu susreće i kao majka i kao supruga. ${ }^{14} \mathrm{Da}$ li žena može da uspešno poveže ulogu majke sa drugima obavezama? Iako su autorke koje su objavljivale u Slovenki imale različite stavove o tom pitanju, uglavnom su se slagale da to nije moguće. Zbog toga se očekivalo čak i od učiteljica da napuste svoje zvanje kad se udaju. Samim ženama je bilo neugodno i činilo im se neprikladnim da ih dečaci-učenici gledaju u trudnoći. Marica Strnad je smatrala da dvostruko opterećivanje može voditi ka potpunom iscrpljenju žene. Nasuprot tome, Zofka Kveder je smatrala da žena može da spoji obe aktivnosti: i materinstvo i profesiju. Katolički pisci su naglasili da žena može da ostvari svoju želju da bude majka i učiteljica ako praktikuje tzv. idealno materinstvo. ${ }^{15} \mathrm{Na}$ njihove ideje humoristički se osvrnula Ivanka

12 Danica [Elvira Dolinar]: Pedagogiške črtice. Slovenka, 1 (1897), 13, 4-5, ovde 5. 13 Danica [Elvira Dolinar]: Višje dekliške šole. Slovenka,1 (1897), 18, 6-8, ovde 7.

14 Zofka Kveder: Kaj hočemo? Slovenka, 4(1900), 10, 232-235.

$15 \lambda$ : Učiteljica in javnost. 5. Idealni poklic. Slovenski učitelj, 19 (1900), 12, 181-183, ovde 182. 
Anžič. ${ }^{16}$ Slovenkine autorke borile su se i sa predrasudama o samohranim majkama. Podsetile su da je nepravedno da samo žena snosi posledice ljubavne veze koja se nije završila brakom. O takvim vezama saznavale su iz mnogih životnih situacija. Takva je, recimo, bila situacija njihove koleginice, pesnikinje Kristine Šuler (1866-1959), koja je zatrudnela sa sveštenikom. ${ }^{17}$ On nije pretrpeo nikakvu štetu, dok je ona morala da nađe posao na drugom kraju Slovenije, na istoku, jer je jedino tamo mogla da radi kao učiteljica i da ujedno bude samohrana majka s vanbračnim detetom. Ta sredina je bila znatno manje puritanska. Ivanka Anžič je pisala i o čedomorstvima i naglasila da bi zajednica i država morale da pruže pomoć trudnim neudatim ženama. Kad je Slovenka prestala da izlazi, o toj temi se raspravljalo u okviru ženskih udruženja, ali i u časopisima koji su kasnije izlazili.

U 20-im i 30-im godinama 20. veka u slovenačkoj štampi već nailazimo na izveštaje i rasprave o samohranim majkama, piše sociološkinja Vesna Leskošek. U Slovenskom narodu moguće je pročitati članke koji govore o tome da lekarke primećuju da kod njih sve češće dolaze neudate žene, koje ne žele brak, ali bi htele da postanu majke. Kao reakciju na takve odluke žena, Slovenec je objavio "Jeremijadu" o detetu koje nije imalo prava da upozna svog oca. Autorka izveštaja $\mathrm{u}$ Slovenskom narodu upozorila je da ima dosta dece koja ne znaju ništa o svojima očevima jer su oni značajna gospoda i veličanstveni velikodostojnici, koji ne priznaju svoju decu. ${ }^{18}$ Vesna Leskošek još tvrdi da se sa zahtevanjem prava na nezavisno materinstvo dogodio interesantan preokret. Pozicija samohranih majki postala je jedan od prioriteta crkve, jer je crkva brinula za javni moral. U tom smislu, neudate majke bile su poželjne i nužne, jer se preko njih realizovala ekonomija ravnoteže u seksualnom i moralnom životu po kriterijumima katoličke crkve, što je dobro uticalo i na vlasnike i na kapital. O ocu niko nije govorio, jer nije bio nužan za podizanje deteta. Siromašna žena bila je ismevana, potisnuta na marginu društva. Žene koje su bile sposobne da same brinu za svoje dete nisu bile pogodna meta progona katoličke crkve. Osim toga, takvo dete bilo je zakonski izjednačeno s onim koje je rođeno u braku. Kako više niko nije mogao

16 Mrakova [Ivanka Anžič]: "Idealno materinstvo”, Slovenka, 4 (1900), 7, 155-159, ovde 157.

17 Prim. Alenka Puhar, "Kristina Šuler (1866-1959). Pesnica in učiteljica, ki je dvignila ceno statusu samohranilke", u: Pozabljena polovica: portreti žensk 19. in 20. stoletja na Slovenskem, ur. Alenka Šelih et al. (Ljubljana: Založba Tuma, 2007), 83-87.

18 Vesna Leskošek, Zavrnjena tradicija: ženske in ženskost $v$ slovenski zgodovini od 1890 do 1940 (Ljubljana: Založba /*cf., 2002), 80. 
da naudi ženskom telu, morao se pronaći novi argument. U vreme razvoja dečjih prava, taj novi argument pronađen je u pravu deteta da ima oca. Drugim rečima, žena je dobra majka samo ako detetu omogući život sa ocem, a to je moguće samo ako stupi u brak. Poželjno je samo ono dete koje je rođeno u braku, jer će u njegovom/njenom životu i razvoju otac biti ključna figura. Ako otac ne utiče na razvoj detetove ličnosti, dete ne može napredovati, društvo ga unapred gubi. ${ }^{19}$ Članke o materinstvu donosi i Ženski svet, koji se u to vreme najviše približava onome što bismo nazvali feminističkim listom..$^{20}$

\section{III}

Reprezentacije majke i materinstva u socijalističkoj štampi samo se na prvi pogled razlikuju od onih u međuratnoj štampi. Prva socijalistička ženska revija Naša žena, ustanovljena 1941. godine, morala je najpre da pridobije čitateljke da bi potom širila aktuelnu ideologiju, piše Nina Vodopivec. Zbog toga je naracija bila u prvom licu jednine, upotrebljavao se dijalog, čime se svakoj čitateljki omogućavalo da se lakše uživi u priču, jer se stvarao utisak da se list obraća baš njoj. U to vreme, žena se posmatra dvojako: ona je odlučna i čvrsta pojedin$\mathrm{ka}$, ali se istovremeno direktnim obraćanjem utiče na njenu žensku osećajnost. ${ }^{21}$ Nina Vodopivec pokazuje da se na osnovu uloga koje su žene imale u NOB-u stvaraju dva tipa idealnih ženskih likova: prvi, za ovaj tekst važan, jeste lik partizanske majke, koja zbog gubitka svojih najmilijih teško pati, ali ne oplakuje svoju sudbinu i ne predaje se očaju, jer njena žrtva ima smisla zbog višeg cilja. Slika takva majke istovremeno aludira na katoličko-hrišćansku Mariju. Obe majke izgubile su sinove koji su dali život za bolju budućnost, ali im zato ostaje vera. Partizanska majka tako postaje "društvena" majka, ona nastavlja sinovljevu borbu. Drugim rečima, ona nije patnji izložena cankarevska majka, nego je borkinja koja je ravnopravna s muškarcem..$^{22}$ Godine 1945. revija Naša žena naglašava važnu razliku između uloge majke pre rata i posle njega. Predratna majka je konkretizovana u drami Majka Karla Čapeka. Ona je, kako je predstavljeno u časopisu, puna sebične materinske ljubavi, hoće da zadrži sinove uz sebe, ne razume

19 Leskošek, Zavrnjena, 81-82.

20 Katja Mihurko Poniž, "Odkar dobivam Ženski svet ne poznam več malodušnosti”, Zgodovina za vse: vse za zgodovino, 16, 2009, 2, 118-132.

21 Nina Vodopivec, "Podoba ženske v listu Naša žena med leti 1945-1951", Kronika 47, 1-2, 1999, 153.

22 Vodopivec, Podoba, 154. 
njihovu želju da umru junačkom smrću. Nasuprot tome, partizanska majka razume tu želju i prati sinove u borbu. Društvena majka spremna je da se podredi višem cilju. ${ }^{23}$ Nina Vodopivec analizira lik majke u Našoj ženi i piše da se bitna promena ogleda upravo u tom pomeranju ženske požrtvovanosti iz privatne u javnu, društvenu sferu. Posle 1948. godine lik jake, snažne radnice, koja radi u teškim uslovima na mašinama, odlazi u drugi plan, a u fokus dolazi žena-majka koja je preopterećena poslom i brigama. Članci u Našoj ženi u kojima se razmišlja o odnosu između žene i dece u prvim godinama posle rata usmereni su uglavnom na vaspitanje. Država, kako Naša žena naglašava, stavlja majku na pijedestal i tako joj javno priznaje važnu ulogu u odgoju dece. Najviše pažnje posvećuje se promenama u pogledu položaja samohranih majki i njihove dece. U časopisu Naša žena o materinstvu se piše kao o dužnosti koja se podrazumeva, dok se očevi hvale za najmanji trud s detetom. ${ }^{24}$ Žena posle rata ima centralnu ulogu kao vaspitačica, jer se odgoj vidi kao javno dobro. Međutim, već od 1950. godine AFŽ ističe da odgoju treba pristupiti kao predodgoju majki. ${ }^{25}$ Naime, društveno vaspitanje treba da preuzmu pionirske i omladinske organizacije, dok majci ostaje emocionalni nivo. U posleratnoj Našoj ženi i dalje se dominatno piše o majci koja je izgubila sve svoje bližnje u ratu. Takva žena-majka je svesna da ne sme da odustane od života zbog gubitka. Okreće se mrtvom sinu koji je poginuo u borbi, i to sa puno nade u majku i sve žene koje su ostale žive. Sinovljeve misli obavezuju je na rad, istrajnost i odlučnost. ${ }^{26}$ Godine 1951. u Našoj ženi se štampa dosta članaka o odnosu majke i deteta. Drugim rečima, kada se uzmu u obzir sadržaj i izgled časopisa, može se reći da Naša žena sve više postaje magazin za majke i decu. Sadržaj je, dakle, izmenjen, nove teme su u prvom planu, poput odgovora na pisma, modnih saveta o haljinama i frizurama pod uticajem francuskih i engleskih kreatora, predloga za bolji život... Naša žena se sve više posvećuje ženi kao pojedinki, njenoj ženstvenoj strani. ${ }^{27}$ Svođenje tradicionalne porodice na vezu između žene i muža i njihove dece američke autorke Barbara Erenrajh i Dirdri Ingliš shvataju kao "romantično rešenje". Žena je podrška mužu koji se trudi da privređuje i izdržava porodicu. Kako je žena izgubila vezu sa izvorom iskustva, to jest s majkom i bakom, treba

23 Vodopivec, Podoba, 155.

24 Vodopivec, Podoba, 157.

25 Vodopivec, Podoba, 157.

26 Vodopivec, Podoba, 164.

27 Vodopivec, Podoba, 166. 
joj stručna pomoć. "Romantično rešenje" zahteva racionalni autoritet - autoritet naučnika. Krajem 19. i tokom čitavog 20. veka svedočimo nečemu što se može nazvati “doba eksperata” - klase psihologa, ginekologa, lekara, jednom rečju stručnjaka, utiču na porodični život svojim savetima, normama i intervencijama. Njihovi saveti postaju deo štampe. Tako počinje istorija društvene anatomije ženske nesigurnosti: ženska štampa nudi pomoć, savete, ali istovremeno omogućuje ženi i da izrazi svoje patnje. ${ }^{28}$ Takvu ulogu u slovenačkoj štampi imaju mnogi časopisi sve do danas.

\section{IV}

Tokom devedesetih, nakon osamostaljenja Slovenije, u zemlji jača nacionalizam, što se posebno odražava na razumevanje materinstva. Pošto desnica dobija na političkoj snazi, u časopisima se ponovo debatuje o tome šta znači biti dobra majka. U Našoj ženi čitamo da majka brine za normalan fizički i psihički razvoj fetusa i rođenje deteta samo ako ona sama živi zdravim životom. Kao što piše Ksenija Vidmar Horvat, stručni diskurs još pre detetovog rođenja ženi puni torbu zalihama krivice. ${ }^{29}$ To nametanje krivice majkama pojačava se po rođenju deteta, pogotovo kod zaposlenih žena. Jedan lekar u Našoj ženi piše kako mu se "cepa srce" kada vidi majku da vodi dete u vrtić u zimsko jutro po magli, te dodaje:

Nema stručnjaka koji bi me ubedio da rano buđenje i ustajanje iz toplog krevetića nije strašan stres za ta mala nežna bića $u$ njihovom naručju. Znam da je mnogo porodica koje zbog siromaštva drugačije ne bi mogle preživeti. Ali vas uveravam da je isto tako mnogo majki koje bi, s obzirom na materijalno stanje porodice, mogle ostati kod kuće - na taj način, njihovo dete bi u svako doba dana imalo topli zagrljaj..$^{30}$

Međutim, takvi članci su ipak retki jer Naša žena, kako pokazuje Vidmar Horvat, više piše o ženama koje spajaju karijeru i materinstvo na način koji ne šteti porodici. U tom slučaju, ističe se da je važna dobra organizacija i pomoć svih članova porodice, kao i racionalno rešenje

28 Vidmar, Zamišljena, 17.

29 Ksenija Vidmar Horvat, "Naša Žena in podoba matere: Navzkrižja in nasprotja, 1991-2001”, u: Njena (re)kreacija: ženske revije v Sloveniji, ur. Majda Hrženjak et al. (Ljubljana: Mirovni inštitut. 2002), 44.

30 Vidmar, Naša, 42. 
- da se žena ne opterećuje previše kućnim poslovima, to jest, da im ne posvećuje preteranu pažnju. U intervjuima na tu temu, slobodno vreme se ističe kao vreme za druge, naročito za decu. Materinstvo se nameće kao tema i u člancima o ženama koje nemaju dece. Takozvano "rezervno materinstvo" se u novinskom diskursu otkriva na simboličnom nivou: slikarka je "majka studentima", rukovoditeljka instituta je "majka instituta, koji je ustanovila...", itd. Istovremeno, novinari i novinarke u intervjuima sa poznatim ženama obavezno postavljaju pitanje o tome kako kombinuju materinsku ulogu sa profesijom. Ksenija Vidmar Horvat zaključuje: "Iz biografskih porodičnih priča sredinom 90-ih godina, korak po korak izrasta slika majke koja je još snažnija i odlučnija da podiže svoje dete, ali i sretnija u svojoj materinskoj realizaciji." ${ }_{31}^{1}$ I u izboru Slovenke godine, koji od 1988. organizuje časopis Jana, simbolično materinstvo je značajno. Slovenke godine su uvek žene koje se žrtvuju za druge ili sve s njima dele. Ako su prve Slovenke godine bile političarke, novinarke ili televizijske zvezde, u doba tranzicije u centru je materinski lik, skroman, koji iz pozadine deluje za druge, a nađe se pod svetlom reflektora tek zahvaljujući organizaciji Slovenke godine. Nakon 2000. godine ikonografija nagrađivanih majki odlazi u drugi plan..$^{22}$

\section{V}

Kakav je odgovor feministkinja na takve slike materinstva? Feministički pokret jača u Sloveniji sredinom 8o-ih godina 20. veka. Kako kaže Vlasta Jalušič, ženski emancipacijski pokret u slovenačkom prostoru sve do devedesetih godina bio je deo "ukupne slovenačke kulturne i nacionalne srži”. ${ }^{33}$ Zbog toga do tada nije uspeo da razvije "autonomne emancipacijske političke strategije". ${ }^{34}$ Tek u osamdesetim godinama taj proces se intenzivira i feministički pokret sve uspešnije izlazi iz "zagrljaja etničkih strategija", ${ }^{35}$ te u cilju rušenja tradicionalnog političkog subjekta stvara drugačiji, paralelni politički prostor u kom nacionalna pripadnost više nije u centru pažnje. U tom razdoblju pokreću se prvi vaninstitucionalni projekti i rasprave $\mathrm{s}$ aktivističkom feminističkom notom. Uz to, zapadna feministička

31 Vidmar, Naša, 41.

32 Ksenija H. Vidmar, Zamišljena, 126.

33 Vlasta Jalušič, Kako smo hodile v feministično gimnazijo (Ljubljana: Založba

/*cf., 2002), 18.

34 Jalušič, Kako, 18.

35 Jalušič, Kako, 18. 
teorija dobija na značaju. Odlučujući događaj u tom smislu bilo je žensko veče grupe Lilit trećeg aprila 1985. godine. Sekcija Lilit je tokom tri godine rada organizovala oko 30 večeri diskusija, izdavala biltene, brošure i organizovala druge aktivnosti. Unutar Lilita formirala se i grupa "lezbična Lilit”. Lilit i druge grupe sa sličnim interesima i ciljevima "bitno su odredile generaciju žena koje su već bile popularne u javnom prostoru ili su se kao liderke mišljenja afirmisale kasnije". ${ }^{36}$ Vlasta Jalušič naglašava da su slovenačke feminističke grupe kod brojnih mlađih liberalnih intelektualaca probudile ne samo osećaj nelagode nego i osećaj pretnje i ugroženosti, a ponekad i neprijateljske ispade koji su se u praksi realizovali kao odbacivanje, vređanje i omalovažavanje. ${ }^{37}$

Interesantan primer jeste nedeljnik Mladina, koji je kao jedan od najvažnijih aktera novog medijskog, javnog i političkog prostora u osamdesetim godinama vodio dvostruku politiku: s jedne strane, davao je prostor feminističkim temama i pokazivao simpatije prema njima ako nisu bile previše radikalne; s druge strane, distancirao se od takvih tema..$^{38}$ U martu 1985. u ovom časopisu izlazi teorijski prilog sa feminističkim tekstovima. ${ }^{39}$ Godine 1986. izlazi i feministički tematski broj Problema, a materinstvo je tema članka Suzan Zimerman. ${ }^{40}$

Prvi slovenački eksplicitno feministički časopis Delta izlazi 1995. godine. Nepotpisan uvodnik naslovljen je parafrazom naziva čuvenog eseja Virdžinije Vulf, kao i važne studije Elejn Šouvolter - A Journal

36 Jalušič, Kako, 39.

37 Jalušič, Kako, 34.

38 Jalušič, Kako, 35 .

39 U njemu čitamo sledeće tekstove: Srna Mandić, "Zakaj v bibliji ni Lilit - prve ženske? Kako naj živim kot poštena gospodinja, potem ko sem živela ob rdečem morju?", Tanja Rener, "Ginofobija ali čarovništvo. O revolucionarnem feminističnem gibanju, ki je z umetnostjo zapeljevanja rušilo diktaturo patriarhata", Gottfried Kössle, "Otroštva deklic v 19. Stoletju”, Susan Brownmiller, "Mit herojskega posiljevalca”, Anne Koedt, "Lezbično gibanje in feminizem"; Mladina 43 (7. 3. 1985); Pogledi (1985), 2.

40 Pored toga objavljeni su sledeći članci: Vlasta Jalušič, "Žensko vprašanje kot izvržek (marksizem, feminizem i klasno pitanje)", Rada Iveković, "Postmodernizam u ženskoj filozofiji”, Mirjana Ule: "O narcizmu ženske", Tanja Rener, "Kamo si šla, oj kje si, Lydia Sklevicky: Obrazci integracije emancipacijskog razvitka AFŽ od 1945. do 1953. godine", Blaženka Despot, "Žensko pitanje i socijalističko samoupravljanje”, Lepa Mlađinović, Biljana Branković, “Gorim za tvoje udisanje”, Susan Zimmerman, "Pravica do samoodločbe pri najemniškem materinstvu", Vanda Krajinović, "Utopijski filmski pogled”, Mojca Dobnikar, "Primer Pariza v Texasu”, Renate Schleiser, "Die totgesagte Vagina”. Problemi 25 (1986), 269. 
of Their Own? U njemu se ističe uverenje da se treba vratiti feminističkoj teoriji i odrediti mesto sa kog se govori. Urednica delom sledi prosvetiteljsku tradiciju: Delta nije časopis o ženama, za žene ili protiv njih, nego je časopis o beskrajnoj razlici, koja je označena grčkim slovom delta, i ne može se ukinuti. ${ }^{41}$ Već u prvom broju nalazi se niz članaka, svojevrsni temat, pod nazivom Materinstvo i reprezentacija. Glavna urednica Eva Bahovec objavljuje članak "Predavanje za uvod: feminizam i materinstvo”. U drugom godištu Sabina Ž. Žnidarič piše o samohranim majkama, Zalka Drglin o deci i majkama i ljubaznom ponašanju u porodilištima. U četvrtom godištu časopis izdaje reprint iz knjige Alenke Puhar o tome kako su Slovenke rađale u prošlosti. Naredne godine (1999) Delta objavljuje članak Eve Bahovec o pogledima na dojenje kod Rusoa i Meri Vulstonkraft, dok je u sedmom godištu objavljen javni poziv za promenu institucionalnih praksi koje se odnose na trudnoću, porođaj i postporođajni period. Godine 2002, u broju 1-2, nalazi se članak Edrijen Rič o Džejn Ejr kao ženi bez majke. U sledećim godištima materinstvo više nije tema pojedinačnih članaka već se analizira u sklopu drugih problema.

Iako je od 90-ih godina 20. veka feministički pokret u Sloveniji na vrhuncu, a ujedno postoji i feministički časopis, feministkinje se ipak ne uključuju u diskusiju oko fotomontaže Majke sa Brezja sa pacovom koju je napravio bend Strelnikoff. U slovenačkoj katoličkoj crkvi nadbiskup i mitropolit Franc Rode počinje svoj mandat 1998. godine. U hodočasničkom središtu na Brezjama napao je 55. amandman slovenačkog Ustava, koji se odnosi na slobodan izbor u vezi s abortusom. Oštar govor izazvao je reakciju Vasje Ocvirka i Sergeja Steblovnika, članova postave Strelnikoff, koji su izdali muzički CD Bitchcraft sa slikom Marije koja umesto Isusa u naručju drži pacova. Ubrzo potom, Rode je odgovorio uvodnikom na samoj naslovnici Družine, časopisa koji izdaje katolička crkva. Mitropolit je čin muzičke grupe ocenio kao najteži napad na crkvu, kakav se nije desio ni tokom pedesetogodišnjeg komunističkog režima i patetično završio: "Beskrajna tuga me je ispunila kada sam vidio tu umotvorinu. Ostao sam bez reči. Nem u svom stidu... tu nema više reči. Tu je sama tuga. Nema tuga i bolest. Majko. Šta su ti uradili!“42 Iako se na prvi pogled diskusija odnosila samo na Majku Božju, jedan dopis u katoličkim novinama Družina pokazuje da je retorika u vezi sa Majkom sa Brezja zapravo i diskusija o ulozi žene u društvu, jer će Marija sa Brezja, kako piše jedna od

41 “A journal of one's own?”, Delta 1, (1995), 1, 7.

42 Franc Rode, "Merili so v srce", Družina 47 (22. 2. 1998), 8, 1. 
vernica (Silva Železnik), ostati slovenački simbol, koji podstiče zdravo materinstvo i predstavlja jedinu alternativu za postojanje slovenačkog naroda. ${ }^{43}$ Autori spornog CD-a su u izjavi za javnost naglasili da nisu želeli nikoga da uvrede. Rekli su:

Mi smo ateisti i nismo članovi nijedne verske sekte, ne verujemo u boga, a još manje u satanu ili bilo koje druge natprirodne sile. Isto tako ne pripadamo nijednoj političkoj stranci. Jednako poštujemo sve ljude, bez obzira na njihovo versko (ne)uverenje ili boju kože. Hoćemo da živimo u slobodnoj zemlji gde svako može da izrazi sopstveni stav, ali i gde svako ima pravo da se s tim mišljenjem ne slaže. ${ }^{44}$

Zbog toga, oni su svoj stav izrekli kroz umetničku formu, odnosno preko muzičkog albuma koji govori o zagarantovanom pravu na abortus. 45

Diskusija o materinstvu u slovenačkoj štampi ponovo se razbuktala uoči dva referenduma: prvi je bio o oplodnji neudatih žena pomoću biomedicine (17. jul 2001), dok se drugi odnosio na predlog novog

43 ”Odmevi, pogledi“ Družina 47 (8.3.1998), 10, 25.

44 Sebastijan Ozmec. "Blasfemija po slovensko. Epilog podganje afere na sodišču”, http://www.mladina.si/97663/blasfemija-po-slovensko/, pristup 18. 12. 2017.

45 Objašnjenje nije uverilo 7000 revnosnih vernika koji su se sastali na Brezjama da bi učestvovali u svečanoj misi organizovanoj u čast uvređene Majke i Kraljice vere. O bolu koji je pretrpelo srce svakog vernika govorio je nadbiskup Rode, koji je ujedno podsetio sve okupljene šta je lik Marije značio našim precima. Krivica je i ovog puta pala na laički vrednosni sistem, a ne na Rodeovu pređašnju brezijansku provokaciju. "Šta je nalilo pelin u ova srca, da ne znaju više poštovati? Je li za to kriva škola, koja više ne poštuje ništa, ili ideologija koja sve što nosi hrišćanski predznak proglašava za bezvredno i prevaziđeno?”, Štefanič, Bogomir ml., "Danes je dan za odpuščanje", Družina 47 (15. 3. 1998), 11, 3. Istovremeno se ironično zaustavio i na estetskom kvalitetu pesme i naglasio da je umetnost samo ono što čoveka uzdiže, veseli i čini plemenitim, a ne ono što ga unižava. Podsticaji duhovnih pastira probudili su Mlade hrišćanske demokrate iz Ljubljane, Slovenske hrišćanske demokrate sa Škofljice, ljubljanske Hrišćanske socijaliste, članove Slovenske konference, ženski savez SKD i 1209 osoba, koji su svi protiv članova benda podneli krivičnu prijavu. Peticiju protiv članova benda potpisalo je još 3867 pojedinca. Anton Drobnič, generalni državni tužilac, dodelio je predmet mariborskom okružnom sudu, koji je potom podigao tužbu protiv muzičara. Optužili su ih da su puštanjem i prikazivanjem materijala s CD-a u lokalu Kljub, kao i objavom u Mladini, izazvali nemire. Međutim, stav suda je bio da uprkos tome što je umetnički projekat bio neukusan, ovaj muzički bend svakako nije prešao dozvoljenu granicu. Sebastijan Ozmec. "Blasfemija po slovensko. Epilog podganje afere na sodišču”, http://www.mladina.si/97663/blasfemija-po-slovensko/, pristup 18. 12. 2017. 
porodičnog zakonika. U prvom slučaju, neudate žene bez partnera mogle bi pred državnom stručnom komisijom da obrazlože razloge i pravo na oplodnju, dok bi u drugom slučaju lezbijski ili gej par mogao da usvoji dete. Oba predloga zakona odbačena su na referendumu. Novinarka časopisa Jana $^{46}$ piše da su se u raspravi o oplodnji neudatih žena pomoću biomedicine javila neka pitanja u vezi sa nepoznatim očinstvom. Recimo, ukoliko se ne zna ko je otac, može doći do incesta. No, važnije od toga, smatra se da svako dete ima elementarno pravo da zna ko mu je biološki otac. Istovremeno, članak ističe i činjenicu da se do 1994. godine oplodnja donorskim ćelijama izvodila i kod neudatih žena, te da novi zakon predstavlja ukidanje već dobijenih prava žena. U članku se nalaze izjave pet žena, poznatih ličnosti, među kojima četiri podržavaju oplodnju neudatih žena. Članak je donekle ambivalentan, jer istovremeno govori o pravima dece i žena, pa svako mora sam da odluči čija su prava važnija ili primarna. Katolička štampa, očekivano, odbacuje ideju o takvom novom zakonu.

Na početku 21. veka u Sloveniji ne postoji feministički časopis koji bi reflektovao konzervativni stav prema materinstvu u društvu i argumentovano pledirao za drugačije prakse. Zato prostor za feministički govor svaka feministkinja pronalazi za sebe u različitim humanističkim i sociološkim časopisima (Anthropos, Časopis za kritiko znanosti, Dialogi, Družboslovne razprave, Monitor ISH, Teorija in praksa...) i u dnevnim novinama. Detaljna analiza feminističkih članaka u svim navedenim časopisima ostaje izazov za nova istraživanja. Međutim, već letimični pregled pokazuje da materinstvo, iako je stalno tema u medijima, za feministkinje izgleda više nije primarna tema. Stiče se utisak da je o materinstvu sve već napisano. Međutim, ne treba gubiti iz vida da istrajno ponavljanje Marijanskog ideala na stranicama katoličke štampe može da dovede do pogubnog efekta: do usvajanja ideje da ne postoji nikakav problem u vezi s tim i takvim idealom majke.

\section{LITERATURA}

A journal of one's own? Delta, 1 (1995), 1, 7.

Accati, Luisa Il mostro e la bella. Padre e madre nell'educazione cattolica dei sentimenti. Milano: Raffaello Cortina Editore, 1998.

46 Žana Kapetanović, "Pasti oploditve z biomedicinsko pomočjo. Neznani sorodniki”, Jana 29 (15. 5. 2001), 20, 11-12. 
Danica [Elvira Dolinar]: "Pedagogiške črtice”. Slovenka, 1 (1897), $13,4-5$.

Danica [Elvira Dolinar]: "Višje dekliške šole". Slovenka, 1 (1897), 18, 6-8.

Jalušič, Vlasta. Kako smo hodile v feministično gimnazijo. Ljubljana: Založba /*cf., 2002.

Kapetanović, Žana. "Pasti oploditve z biomedicinsko pomočjo. Neznani sorodniki”. Jana br. 20 (15. 5. 2001): 11-12.

Kumer, Zmaga. Marija v Svetem pismu in slovenskih ljudskih pesmih. Ljubljana: Družina, 2004.

Kveder, Zofka. “Kaj hočemo?” Slovenka, 4 (1900), 10, 232-235.

Leskošek, Vesna. Zavrnjena tradicija: ženske in ženskost $v$ slovenski zgodovini od 1890 do 1940. Ljubljana: Založba / *cf., 2002.

l: Učiteljica in javnost. 5. Idealni poklic. Slovenski učitelj, 19 (1900), $12,181-183$.

Mahnič, Anton. "Žensko poglavje. Naravni poklic ženske: bodi mati pa vzgajaj deco!” Rimski katolik, 6 (1894): 359-36o.

Mihurko Poniž, Katja, "Odkar dobivam Ženski svet ne poznam več malodušnosti”, Zgodovina za vse: vse za zgodovino, br. 2 (2009): 118-132.

Mlekuž, Jernej. "The newspaper images of aleksandrinke and the national imagination”. U From Slovenia to Egypt: Aleksandrinke's trans-Mediterranean domestic workers' migration and national imagination, ur. Mirjam Milharčič Hladnik (Transkulturelle Perspektiven, Bd. 13). Göttingen: V\&R Unipress. 2015, 173-192.

Mrakova [Ivanka Anžičc]: Idealno materinstvo. Slovenka, 4 (1900), 7, 155-159.

“Odmevi, pogledi” Družina br. 10 (1998): 25.

Ozmec, Sebastijan. Blasfemija po slovensko. Epilog podganje afere na sodišču. http://www.mladina.si/97663/blasfemija-po-slovensko/, pristup 18. 12. 2017.

P.E.Z., "Slaba mati, hudoben sin”. U Drobtince, ur. A. M. Slomšek (Graz: Lajkam, 1848), 184.

Pogačnik, Jože. Slovenska Lepa Vida ali hoja za rožo čudotvorno. Motiv lepe Vide $v$ slovenski književnosti. Ljubljana: Cankarjeva založba, 1988. 
Puhar, Alenka. "Kristina Šuler (1866-1959). Pesnica in učiteljica, ki je dvignila ceno statusu samohranilke". U Pozabljena polovica: portreti žensk 19. in 20. stoletja na Slovenskem, ur. Alenka Šelih et. al, Ljubljana: Založba Tuma, 2007, 83-87.

Rode, Franc. "Merili so v srce”, Družina, br. 8 (1998): 1.

Slomšek, Anton Martin. "Skerbna mati v soboto zvečer". U Drobtince, ur. A. M. Slomšek, 209-212. Graz: Lajkam, 1848.

Štefanič, Bogomir ml. “Danes je dan za odpuščanje.” Družina br.11, (15.3.1998), 3 .

Verginella, Marta ur., Slovenka: prvi ženski časopis (1897-1902). Ljubljana: Znanstvena založba Filozofske fakultete, 2017.

Vidmar Horvat, Ksenija. "Naša Žena in podoba matere: Navzkrižja in nasprotja, 1991-2001.” U Njena (re)kreacija: ženske revije v Sloveniji. Ur. Majda Hrženjak et al. Ljubljana: Mirovni inštitut, 2002.

Vidmar Horvat, Ksenija. Zamišljena mati: nacionalizem in spol $v$ kulturi 20. Stoletja. Ljubljana: Znanstvena založba Filozofske fakultete, 2012.

Vodopivec, Nina. "Podoba ženske v listu Naša žena med leti 19451951”, Kronika br. 1-2, (1999): 153-167.

Žižek, Slavoj. Jezik, ideologija, Slovenci. Ljubljana: Delavska enotnost, 1987.

Warner, Marina. Alone of All Her Sex: The Myth and the Cult of the Virgin Mary. London: Picador, 1990.

\section{DISCOURSE ON THE MOTHERHOOD IN SLOVENIAN FEMINIST PRESS}

The article focuses on the discourse of the motherhood in Slovenian press from its beginnings in the 19th century until recent days. The motherhood represents one of the strongest ideologies in the Slovenian society and has therefore triggered ongoing discussions in the Slovenian press, especially in catholic, women's and feminist press. An image of a mother who sacrifices herself for the good of her children is deeply rooted in the Slovenian cultural memory with the figure of the Virgin Mary and with the figure of a self-denying mother in the writings of the Slovenian writer Ivan Cankar (1876-1918). The opposite 
image of a bad mother is represented in the figure of the Fair Vida from the folk songs, who leaves her child and husband for a better life. The Catholicism and nationalism have always tried to suppress representations of motherhood differing from those that enable the legitimisation of their own views on self-denying motherhood. On the other hand, feminist voices, expressed in first Slovenian women's magazine Slovenka (1897-1902), have strongly opposed the reductions of motherhood on the self-sacrificing mother and have emphasized that the motherhood is not women's only vocation and profession. This view had been theoretically further developed, as the article shows, in the first Slovenian feminist magazine Delta (1991-2007).

Keywords: motherhood, Slovenian feminist press, magazines Slovenka, Naša žena, Delta 